\title{
O ATOMISMO METAFÍSICO DA ANTIGUIDADE GREGA
}

\author{
Eduardo Simões ${ }^{1}$ \\ Universidade Federal do Tocantins (UFT) \\ (iD) https://orcid.org/0000-0001-7375-8574
}

\begin{abstract}
RESUMO:
O objetivo do presente texto é o de apresentar as bases do atomismo metafísico a partir da produção do conhecimento na Antiguidade Clássica. Não se trata de abrir qualquer tipo de discussão acerca da produção do conhecimento contemporâneo sobre a realidade do átomo. Trata-se de apresentar os fundamentos teóricos de base grega, cujos reflexos foram sentidos nos desenvolvimentos posteriores do atomismo metafísico. Sendo assim, a pretensão não é a de apresentar um trabalho específico de História da Filosofia ou de História da Ciência, mas sim, de um estudo da Filosofia da Ciência no contexto de sua história; pois, diante da questão sobre qual seria a competência epistêmica que delimita a Filosofia em sua essência, não encontramos outra maneira de tentar determiná-la a não ser consultando sua própria história.
\end{abstract}

PAlaVRAS-CHAVE: Filosofia; Ciência; Antiguidade; Átomo; Metafísica.

\section{THE METAPHYSICAL ATOMISM OF GREEK ANTIQUITY}

\begin{abstract}
:
The purpose of this paper is to present the foundations of metaphysical atomism from the production of knowledge in classical antiquity. It is not necessarily opening any kind of discussion about the production of contemporary knowledge about the reality of the atom. It is to present the
\end{abstract}

\footnotetext{
1 Doutor em Filosofia pela Universidade Federal de São Carlos (UFSCar) - Brasil. Professor do curso de Filosofia da Universidade Federal do Tocantins (UFT) - Brasil. Atua especialmente com os temas Filosofia da Ciência e da Tecnologia, Epistemologia, Lógica e Filosofia da Linguagem. E-mail: eduardosimoes@mail.uft.edu.br
}

O atomismo metafísico da antiguidade grega - Eduardo Simões 
theoretical foundations of Greek base, whose effects were felt in later developments of the metaphysical atomism. Thus, the intention is not to present a specific work of the History of Philosophy and History of Science, but rather a study of the philosophy of science in the context of its history; therefore faced the question of what would be the epistemic competence that defines philosophy in its essence, we found another way to try to determine it unless referring to his own story.

KEYWORDS: Philosophy; Science; Antiquity; Atom; Metaphysics.

Há no interior das ciências naturais a pretensa resistência em considerar uma verdade que lhe parece peculiar, mas que, por sua necessidade de prova empírica, muitas vezes prefere ignorar: a de que teorias científicas, quase sempre travestidas de uma suposta objetividade, podem trazer no seu interior uma robusta metafísica resistente aos dados experimentais. Isso acontece, por exemplo, com a identificação contemporânea da realidade do átomo e de sua estrutura. Até que ponto a indicação de elementos atômicos (ou subatômicos) aponta para a realidade material? O constitui, de fato, substância física ou entidade metafísica em tais elementos? Qual elemento serve para o cumprimento de uma necessidade lógica dedutiva de funcionamento do sistema e qual, de fato, existe? A inexistência do "elemento $\mathrm{x}$ " não colapsaria todo o sistema? A existência do "elemento y" não pressuporia a inteligibilidade do sistema? Questões próprias do materialismo, que têm sido fruto de discussões históricas a respeito da realidade do átomo não foram, necessariamente, fruto da preocupação antiga com a sua suposta materialidade. Mais do que uma preocupação com a necessidade de uma prova objetiva, material, estavam os gregos, desde Leucipo, preocupados com a função lógica desempenhada pelo átomo no interior de seus sistemas. Por isso, desencadearam uma série de explicações, cuja coerência lógica era a exigência de fundo, onde o átomo desempenhou o papel não de coadjuvante, mas de protagonista de argumentos nos quais erigiu-se como fundamento e base.

Diante do exposto, a intenção do presente texto, muito mais do que o da defesa de qualquer ponto de vista, ou mesmo de qualquer tese, visa elucidar algumas questões que serão de capital importância no entendimento da realidade do átomo na Antiguidade grega. Trata-se, assim, de um texto propedêutico e elucidativo para os não-iniciados em Ciência. Para os qualificados, resta um breve passeio pelos caminhos da História Física, recapitulando temas supostamente dissecados, elucidados e resolvidos pela comunidade dos cientistas, mas cuja atualidade não se perdeu. A despeito dos que não têm tal profundidade no tratamento do desenvolvimento da História da Ciência, ou dos que não conseguem vislumbrar que em seu interior houve (e há) lugar para o desenvolvimento da metafísica, as 
discussões que se seguem tornar-se-ão substanciais, visto que é da produção grega que se parte os desenvolvimentos posteriores acerca do entendimento do atomismo e de seus desdobramentos.

Os períodos da filosofia antiga que aqui serão abordados referem-se, primeiramente, ao período naturalista (século VI a.C.) cuja principal preocupação é com o problema da "physis" (quando se procura por um princípio substancial responsável pela ordenação de todas as coisas), e terá como culminância a filosofia helenística, com a análise do atomismo de Epicuro e Lucrécio. A preocupação principal nessa análise, não será necessariamente com a ciência nascente e seus reflexos sobre uma sociedade radicada na cultura mítica. O foco será, portanto, na visão cosmo-ontológica dos gregos e seus reflexos para as primeiras propostas de uma realidade fabricada. E o protagonista dessa discussão que entra em cena com toda sua força, apresentando-se de tempos em tempos com novas roupagens, mas nunca excluído do imaginário coletivo de nossos cientistas/filósofos, é o "átomo", que compõe uma realidade que, até em seu nível mais fundamental ou subatômico, segundo observou Heisenberg (1995, p. 27) ${ }^{2}$ é uma realidade muito mais "criada" do que "observada" pelos físicos" ${ }^{3}$.

Poderíamos iniciar essa exposição diretamente com as filosofias atomísticas de Leucipo e Demócrito, assim, já teríamos assegurado o entendimento de como a fabricação da realidade se deu entre os gregos. No entanto, entender a necessidade de postular as partículas elementares, pressupõe entender quais discussões que as precederam, o que sugere uma breve retroação.

A física e a filosofia confundem suas origens na aurora do pensamento grego; não é sem razão que a doxografia antiga denominou os primeiros filósofos de "oi physikói”, "os físicos", tendo sido eles os primeiros a empreenderem uma importante superação do pensamento mítico em favor do "entendimento" racional da ordem do universo. Como é sabido, foi na Jônia que surgiram as primeiras concepções científicas e filosóficas da cultura ocidental. Os primeiros filósofos teriam sido os pensadores de

${ }^{2}$ O físico contemporâneo, criador do "Princípio da Incerteza", diz: "Nossa situação concreta, o trabalho de pesquisa em física atômica, é usualmente a seguinte: desejamos entender um certo fenômeno, queremos reconhecer como esse fenômeno decorre das leis gerais da natureza. Portanto, aquela parte de matéria, ou de radiação, que toma parte no fenômeno é o 'objeto' natural no tratamento teórico e deveria ser separado, nesse respeito, dos instrumentos utilizados no estudo de fenômeno. Isso de novo realça o elemento subjetivo na descrição dos eventos atômicos, pois o instrumento de medida foi construído pelo observador, e temos que nos lembrar que aquilo que observamos não é a natureza em si, mas, sim, a natureza exposta ao nosso método de questionar. Nosso trabalho científico, em física, consiste em fazer perguntas sobre a natureza, usando a linguagem que possuímos e tentando conseguir as respostas por via experimental, com os meios que dispomos".

3 Os átomos serão introduzidos como realidade ontológica no interior das teorias da mecânica como explicação para os fenômenos da ação à distância. A posteriori, especialmente depois de Descartes e Newton, é o éter que toma seu lugar quando utilizado para explicação dos fenômenos eletromagnéticos.

O atomismo metafísico da antiguidade grega - Eduardo Simões 
Mileto: Tales, Anaximandro e Anaxímenes. Também faz parte da escola jônica Heráclito de Éfeso.

Procurando reduzir a multiplicidade à unidade exigida pela razão, os pensadores de Mileto propuseram sucessivas versões de uma física e de uma cosmologia constituídas em termos qualitativos: qualidades sensíveis (frio, quente, leve, pesado, etc.) eram entendidas como realidades em si ("o frio", "o quente", "o leve", "o pesado") e o universo era concebido como um conjunto no qual se contrapunham os pares opostos. O mais antigo filósofo reconhecido como tal é Tales de Mileto. Não se tem informações precisas sobre seu nascimento e morte, o que se sabe é que ele estava no apogeu aproximadamente no ano de 585 a.C. - data em que teria previsto o eclipse do sol de 28 de maio. Atribui-se a Tales muitas contribuições para o conhecimento, a saber: que sustentou pela primeira vez a imortalidade da alma, que foi o primeiro a determinar o curso do sol de solstício a solstício, que definiu o tamanho o sol como à $720^{\mathrm{a}}$ parte do círculo solar, que foi o primeiro a dar ao último dia do mês o nome de trigésimo e o primeiro a discutir problemas físicos (LAÊRTIOS, 2008, p. 18). Em geometria foi o primeiro demonstrou que o diâmetro divide o círculo em duas partes iguais, que os ângulos da base de um triângulo isósceles são iguais, que encontrou um método para medir a altura das pirâmides, medindo sua sombra no momento em que ela é regularmente igual ao tamanho de seu corpo, etc. Mas, o mais importante para os nossos propósitos é o que Tales concebe como "arché", como elemento constitutivo de todas as coisas (sentido atribuído a essa palavra entre os pré-socráticos).

Segundo Aristóteles (1969), o princípio material sustentado por Tales é "a água". E o que justifica a escolha de tal princípio é o fato de que "a terra flutuava sobre a água", "que todo alimento é úmido", que o "calor retira do úmido geração e vida", "que a semente de todas as coisas tem uma natureza úmida", de tal forma que "a água é o princípio da natureza de todas as coisas úmidas". Além do que, a água pode assumir as mais numerosas e variadas formas: pode surgir como gelo e neve, transformar-se em vapor e formar nuvens, parece transformar em terra nos deltas dos rios. Enfim, ela é um elemento vital e é natural que, ao pensar em um elemento primordial, a água apareça em primeiro lugar. Portanto, Tales apresenta uma realidade ainda não fabricada, muito provavelmente, assumida a partir de suas observações meteorológicas. Mas, o que pretendemos é identificar onde essa realidade começa a ser uma fabricação nossa, com todas as suas bases materiais passíveis de questionamento.

A busca por um elemento primordial foi levada adiante por Anaximandro (611-546 a.C.), discípulo e concidadão de Tales. Para Anaximandro tal elemento não poderia ser o princípio, mas derivaria desse princípio, chamado de por ele "ápeiron", privado de "peras" (de limites ou determinações), que compreende uma infinidade de realidades e mesmo de mundos possíveis. O ilimitado é a causa universal de toda geração e 
corrupção e o mesmo pode se transformar nas várias substâncias com as quais estamos familiarizados. É o conflito eterno entre o Ser o e Vir-a-ser: o primeiro, o imutável, vê sua forma se degradar no vir-a-ser, mas, no entanto, permanece incorruptível ${ }^{4}$. É essa luta eterna entre os contrários a responsável pela criação do mundo: "o quente é oposto ao frio, o seco ao molhado, etc. Esses opostos combatem entre si e qualquer predominância de um sobre o outro é vista como uma 'injustiça', razão pela qual os opostos devem oferecer reparação, um ao outro no tempo marcado" (HEISENBERG, Op. Cit., p. 50). Nota-se que Anaximandro não apresenta nenhum elemento como sendo o elemento constitutivo de todas as coisas (nem a água, nem o ar, nem a terra e nem o fogo), ao contrário, introduz em sua filosofia um elemento ad hoc responsável por toda geração e corrupção. Temos aí a primeira concepção ontológica de mundo: o que seria o ápeiron do milesiano? Qual a justificativa para a introdução de tal elemento em sua teoria? Qual a necessidade subjacente a tal construção? Sem que tenhamos uma resposta definitiva quanto a tal necessidade, resta-nos conjecturar que a introdução do ilimitado como o "princípio" constitutivo de todas as coisas deve-se a uma necessidade implícita, a saber, a de dar um caráter de necessidade ao seu pensamento. O "ápeiron", dentre outras coisas, possibilita a universalidade do "sistema" de Anaximandro, na medida em que se torna eterno. Temos aí a primeira concepção de realidade mais criada (ou totalmente criada) do que observada. E é a partir daqui que essa prática se torna comum no pensamento ocidental.

Quanto a Anaxímenes (metade do séc. VI a.C.), discípulo e continuador de Anaximandro, esse renunciou a ter por princípio o ilimitado, e o ar toma o lugar de matéria ou substrato, que por rarefação e condensação, engendra todos os seres: condensando-se e reunindo-se ele dá origem a água e a terra, enquanto rarefazendo-se e dilatando-se dá origem ao éter e ao fogo e, retomando sua própria natureza, volta a ser ar.

Como foi afirmado, os filósofos de Mileto propuseram uma física e uma cosmologia constituídas em termos qualitativos. Foi Pitágoras (582-500 a.C.), no entanto, quem promoveu uma virada no modo de pensar présocrático quando propôs uma matematização da experiência humana, reduzindo a análise da qualidade à quantidade e traduzindo os fenômenos naturais em termos matemáticos.

Conta-se que a escola pitagórica funcionava como uma espécie de seita; os pitagóricos levavam uma vida monástica na qual, após uma iniciação de duração variável, completava-se primeiro um noviciado de três anos (para os acusmáticos ou fiéis), seguido de cinco anos de silêncio (para os matemáticos ou sábios). Diz-se ${ }^{5}$ também que Pitágoras teria sido o

\footnotetext{
4 "Disse também que as partes sofrem mudanças, porém o todo é imutável" (LAÊRTIOS, 2008, p. 47).

5 As expressões "conta-se", "diz-se", devem-se ao fato da incerteza quanto à vida de Pitágoras que não deixou nenhum documento escrito. Seus ensinamentos, conforme
} 
inventor da palavra Filosofia quando interrogado pelo tirano de Fliús sobre “quem era ele, respondeu: 'um Filósofo'. Comparava a vida aos Grandes Jogos, aos quais alguns compareciam para lutar, outros para fazer negócios, e outros ainda - os melhores - como espectadores; com efeito, alguns crescem escravos da fama, outros ambiciosos de ganho, e os filósofos ávidos da verdade" (LAÊRTIOS, Op. Cit., p. 230). Mas, o que nos é relevante é como Pitágoras concebe a realidade e o que ele entende ser o princípio de todas as coisas.

Quanto à realidade, a mesma é formada pelo número e pelo Universo governado pela harmonia. O número é a essência de todas as coisas, todas as coisas são números. Matemática, especialmente geometria, foram suas paixões. Quanto à geometria, além de aperfeiçoá-la, dedicou ao estudo do aspecto aritmético da mesma: descobriu o cânone monocórdio e que o quadrado da hipotenusa num triângulo retângulo é igual à soma dos quadrados de seus catetos. O filósofo admitia que a mais bela das figuras sólidas era a esfera e das planas, o círculo. Mais ainda, os pitagóricos associavam os quatro elementos da natureza aos sólidos regulares: a terra ao cubo, o fogo à pirâmide, o ar ao octaedro e a água ao icosaedro e, com isso, reduziam todas as coisas do cosmo ao número ou à inteligibilidade do pensamento.

Quanto ao princípio de todas as coisas, tal como concebia Pitágoras, Diógenes Laércio diz que Alexandre (historiador da primeira metade do século I a.C.) teria afirmado em suas Sucessões dos Filósofos que nas Memórias Pitagóricas havia prescrito que "a mônada é o princípio de todas as coisas". Produzida pela mônada, a díade indefinida existe como seu substrato material, cuja causa é a própria mônada. São a mônada e a díade indefinida que engendram os números, dos números nascem os pontos, dos pontos nascem a linhas e das linhas nascem as figuras planas, as quais produzem figuras tridimensionais. "Destas nascem os corpos perceptíveis pelos sentidos, cujos elementos são quatro: o fogo, a água, a terra e o ar. Esses elementos transmudam-se para produzir um cosmo animado, inteligente, esférico, tendo em seu centro a terra" (LAÊRTIOS, Op. Cit., p. 234). O texto não diz como se efetua essa geração e isso é mais uma denúncia de que a concepção pitagórica de realidade trata de uma realidade fabricada, onde o ideal de natureza é muito mais fundamentado na imaterialidade e inteligibilidade matemática do que na observação empírica. Certo é que o pitagorismo exerceu profunda influência na filosofia grega posterior, quer pela reação polêmica que provocou (em Xenófanes, Heráclito, Parmênides, Zenão de Eléia), quer pelos pontos positivos que passaram para os pensadores posteriores. Mas, interessa-nos muito mais as polêmicas. Delas podemos extrair exemplos imediatos de como a realidade,

Diógenes Laércio, eram transmitidos oralmente e guardados em segredo por seus primeiros discípulos que, também, nada escreveram. Daí a dificuldade de distinguir o que era realmente de Pitágoras das ideias de seus discípulos tardios. 
a partir de então, perde de vez o caráter de realidade ipso facto. E Parmênides é o principal responsável.

Representante da Escola Eleata, fundada no começo do século VI a.C. por Xenófanes, Parmênides (530-460 a.C.) juntamente com Melisso e Zenão de Eléia formavam o corpo dos três filósofos mais ilustres dessa escola. Em busca de um princípio de inteligibilidade, os eleatas situavam esse princípio no Deus Uno de Xenófanes, no Uno e no Ser de Parmênides e Melisso, ou ainda, no Uno-múltiplo de Zenão. Sempre colocando a identidade do ser com o que o intelecto apreende.

Enquanto os pitagóricos pensavam na imaterialidade e inteligibilidade enquanto fundamento do cosmo, Parmênides elabora algo completamente novo na filosofia que vinha sendo construída: com ele a cosmologia (preocupação dos jônicos e dos pitagóricos) transforma-se em ontologia. E é aqui que os nossos interesses se firmam.

A atitude polêmica de Parmênides contra os pitagóricos gira em torno, primeiramente, do dualismo defendido pelos primeiros: o princípio de todas as coisas é a mônada (um princípio único ou o Uno); da mônada vem a díade indefinida (a matéria ou "o dois" que é uma emanação do princípio Uno); em terceiro lugar vem o número, cujos elementos são o par e o ímpar (sendo o primeiro ilimitado e o segundo limitado); e o Uno deriva desses dois elementos, pois ele é ao mesmo tempo par e ímpar. Por fim, o número deriva do Uno e o céu em sua totalidade é número (ARISTÓTELES, $O p$. Cit., A, 5.986 a 15). Como consequência do dualismo pitagórico, nota-se que o Uno não é mais o primeiro, e a ordem então seria: I) os Princípios: limitado e ilimitado, II) os Elementos: ímpar e par, III) O Uno, a mistura e IV) O Número.

Parmênides rejeita esse dualismo e seus reflexos: o ser e o não-ser, o cheio e o vazio, o móvel e o imóvel. E em vez de perguntar qual é a origem do cosmo e de responder "é o número", ou "os contrários", ou "a água", ou "o ar", prefere concentrar-se na natureza própria do saber, que demonstra ser indissociável do ser. É assim que a ontologia se sobrepõe à cosmologia. Em segundo lugar, polemiza contra os pitagóricos visto que ele não concebe a existência do vazio; e isso por razões lógicas: o não-ser - o vazio - não pode existir. Quando se assume que toda mudança requer espaço vazio, assume-se a existência de tal espaço, e para não ter que se submeter a tal aceitação, Parmênides radicaliza em rejeitar a ideia de mudança por considerá-la uma ilusão.

Nos fragmentos de seu texto que chegou até nós, intitulado $D a$ Natureza, a partir de um suposto diálogo com a deusa, fica-nos explícita a radical oposição entre o ser (que é pensado) e o não-ser: "É necessário que o ser, o dizer e o pensar sejam; pois podem ser, enquanto o nada não é" (PARMÊNIDES, 2002. p. 15). E o ser é ingênito, indestrutível, compacto, inabalável, sem fim e sem princípio, homogêneo, uno, contínuo, indivisível, imóvel, etc. Já, quanto ao não-ser, nada se pode falar a respeito dele, nem 
pensar sobre ele, "pois não é dizível, nem pensável, visto que não é" (PARMÊNIDES, Op. Cit., p. 16). Quanto à via da verdade, da investigação, essa pressupõe dois caminhos: "um que é, que não é para não ser", e "o outro que não é, que tem de não ser" (PARMÊNIDES, Op. Cit., p. 14). O paradoxo de Parmênides encerra-se no seguinte fato:

A relação entre o primeiro e o segundo caminho é evidente: o que um afirma o outro nega. Que sucede, porém, se a cada um deles aplicamos a indicação do outro (negando o primeiro e afirmando o segundo)? A resposta não pode ser mais simples: caímos no segundo e voltamos ao primeiro (a negação nega a afirmação e a dupla negação é a esta equivalente) (SANTOS, 2002, p. 66).

Desse paradoxo podem-se extrair consequências lógicas interessantes quando se admite que através do pensamento só se pode afirmar ou negar: quando a afirmação é igual à afirmação e a negação é igual à negação $(\mathrm{A}=\mathrm{A})$ tem-se o princípio da identidade; quando a afirmação é diferente da negação $(\mathrm{A} \neq \sim \mathrm{A})$ tem-se o princípio da contradição; e quando entre a afirmação e a negação não há um terceiro termo (AV A) tem-se o princípio do terceiro excluído. Essas são as consequências do paradoxo de Parmênides.

O que os jônicos e os pitagóricos pretendiam com suas filosofias era encontrar na natureza um princípio que fosse concorde com a razão e, em consequência disso, acreditavam que o mundo da experiência real participava da natureza do pensamento, de modo que a razão poderia ser o princípio de investigação. Parmênides radicaliza essa ideia ao admitir que o ser e o pensar são a mesma coisa, isso é, a estrutura do ser e do pensamento é uma e a mesma - “[...] pois o mesmo é pensar e ser" (PARMÊNIDES, Op. Cit., p. 15). Uma vez que a estrutura fundamental do ser é a mesma estrutura do pensamento, isso significa que investigando a estrutura fundamental do segundo, estaremos investigando a estrutura do primeiro.

Certo é que Parmênides legou à filosofia posterior o como proceder à reconstrução do mundo fenomênico respeitando um princípio supremo, a saber, afirmando o ser e negando o não ser. Mas, com isso, ele também cria um problema para a filosofia ulterior: como conciliar o ser parmenidiano com o que a experiência nos apresenta? Como reconhecer qualquer coisa no mundo que se identifica com tal ser? Ou mesmo, como proceder à reconstrução fenomênica do mundo afirmando o ser e negando o não-ser? Quem aceitará a empreitada da resolução desse problema serão Leucipo e Demócrito que, mesmo admitindo (como Parmênides) a não inteligibilidade da gênese e corrupção, tentam conciliar essa "realidade" com os fatos da experiência cotidiana.

Sobre a vida de Leucipo não se sabe quase nada. Aristóteles o considera como o criador do atomismo que foi a posteriori desenvolvido 
por Demócrito. Portanto, é no atomismo de Demócrito (460-370 a.C.) que se firmam as discussões subsequentes.

A primeira proposta aqui apresentada é a sustentação de que as teses do atomismo se servem de resposta à ontologia de Parmênides e, ao mesmo tempo, superam-na no sentido de apresentar um elemento novo que, ao menos, pode ser "pensado" em termos de "realidade" apreendida (pelo menos é o que se pretende na Física contemporânea). No entanto, sem querer apressar respostas que, supostamente, serão encontradas através da análise, afirma-se, também, que esse mesmo atomismo é muito próximo tanto do pensamento pitagórico, quanto do pensamento dos eleatas - na medida em que se afastam, aproximam-se.

Átomo é uma palavra grega que significa indivisível. Para os atomistas os princípios que permitem explicar a realidade são os átomos e o vazio; o que nos permite, desde já, apresentar esses elementos como uma transposição do ser e do não-ser de Parmênides. Segundo Dumont (2004), a tradição diz que três são as origens possíveis do atomismo grego: em primeiro lugar, a inspiração para o mesmo seria de Mileto, especificamente, de Anaximandro e de seus alunos. "O infinito, ou o ilimitado, é substituído pela infinitude em número de átomos. Estes são corpos capazes, quando reunidos, de engendrar corpos materiais" (DUMONT, Op. Cit., p. 130). Em segundo lugar, os átomos tal como concebidos, aproximam-se dos números dos pitagóricos em inteligibilidade (são apreendidos pela inteligência) e, assim como os números, servem-se como elementos cujos sensíveis são por eles construídos. E, por fim, a influência eleata aparece mais forte, por três fatores: a) os átomos estão para o ser, como o vazio está para o não-ser - um não-ser necessário aos átomos, pois, na verdade, trata-se do seu espaço de locomoção (ao vazio é atribuído um certo ser); b) os átomos são seres inteligíveis que somente o intelecto pode conceber; e c) a oposição democritiana entre intelecção e opinião restitui o dualismo do poema de Parmênides: os átomos representam as ideias, enquanto as qualidades sensíveis não existem senão para os sentidos e opinião.

De que maneira se pode entender a teoria de Demócrito? Uma primeira coisa que deve ser observada no sistema democritiano é que os elementos átomos e vazio preenchem a necessidade básica de justificar todos os fenômenos. Sendo assim, a locomoção dos átomos, sua configuração e desarranjo, explicam, por uma causalidade puramente mecânica, o conjunto de toda existência. Em seu sistema não se encontra nenhuma espécie de teleologia; nada na natureza remete a um fim diferentemente de Aristóteles, ele não trata da causa final, tudo é delegado ao puro acaso (os átomos agrupam-se e reagrupam-se ocasionalmente para formar todos os elementos). Tudo acontece por força do acaso, ele é o redemoinho causador da origem de todas as coisas. Diógenes Laércio atribui a Demócrito a ideia de que os mundos são infinitos, sujeitos à geração e ao perecimento, isso porque, tais mundos são formados por átomos que se 
locomovem no vazio para lhes formar. Tais átomos, portanto, são divisíveis do ponto de vista matemático, mas indivisíveis do ponto de vista físico e não apresentam propriedades físicas como cor, odor ou sabor. Nada é gerado pelo não-ser e nada perece no não-ser. Os átomos são infinitos em tamanho e número; movem-se como um vórtice e geram assim todas as coisas compostas: fogo, água, ar e terra. Essas, por sua vez, são elementos que também são uniões de determinados átomos, que por sua solidez são impassíveis e imutáveis. Até mesmo o sol e a lua se compõem de tais massas atômicas lisas e esféricas, e igualmente a alma, que é idêntica à mente (LAÊRTIOS, Op. Cit., p. 263). Com relação à mente, à inteligência ou ao conhecimento, Demócrito formula a oposição inteligência $\mathrm{x}$ sensivel e toma por única verdade a compreensão dos inteligíveis: apenas os átomos e o vazio podem ser objetos de um saber seguro. Tudo o que é sensível depende da opinião; as qualidades sensíveis dos corpos não são reais, mas imaginárias. Demócrito é citado por Galeno (2000, p. 282) como tendo dito que "por convenção há cor, por convenção há o doce, por convenção há o amargo, mas na realidade há somente os átomos e o vazio". A única realidade é constituída pela realidade inteligível dos átomos, pelas ideias; por outro lado, a realidade dos corpos sensíveis e suas qualidades são recusadas pelo abderiano.

A mecânica atomística de Demócrito funciona da seguinte maneira: primeiramente, os átomos são qualitativamente idênticos (o que diferencia é o arranjo - figura, ordem e posição - e não o átomo em si): "Pois as diferenças do ser resumem-se ao ritmo, à associação, e à modalidade. O que eles chamam de ritmo é a figura, associação é a ordem e a modalidade é a posição. Assim, A é diferente de $\mathrm{N}$ pela figura, AN de NA pela ordem e I de $\mathrm{H}$ pela posição"6. Essas diferenças tornam-se mais claras no seguinte comentário: "O sabor amargo é produzido por · átomos pequenos, lisos e redondos, cuja atual circunferência é sinuosa, e por isso é viscosa e pegajosa. O sabor ácido é causado por átomos grandes, não-redondos e, às vezes, até angulosos" (ARISTÓTELES, Op. Cit., A, 4.985 b 4). Portanto, os átomos possuem as mais variadas formas, o que justifica a diferenciação de cada um dos seres e elementos da natureza. Por exemplo, os elementos água, fogo, terra e ar são definidos pelo tamanho e pela forma dos átomos: água, terra e ar são diferenciados pelo tamanho dos átomos. Por outro lado, odor e sabor, são explicados pela forma atômica. Já os cheiros e sabores agradáveis, como o doce, estão associados aos átomos arredondados e lisos. Quanto às cores, estas são definidas pelo arranjo dos átomos de um corpo: quando os arranjos dos átomos se alteram na superfície de um corpo,

\footnotetext{
6 “A letra I (iôta maiúsculo, escrito com duas longas barras, inferior e superior) é idêntica à letra H (êta maiúsculo) que não é senão um iôta deitado. A geração dos corpos é um efeito da escritura ou da associação tipográfica. Notemos ainda que o uso das letras deitadas corresponde à notação musical. Assim, à harmonia pitagórica substitui uma escritura musical, a ser colocada em paralelo com o ritmo" (DUMONT, Op. Cit. p. 132).
} 
consequentemente, há uma mudança de cor. Mas, o que atesta a mudança da propriedade de um elemento, por exemplo, sua cor? Essa percepção não está no próprio objeto, ela é subjetiva. No entanto, existe um sustentáculo causal para ela, o que torna inteligível sua alteração. As coisas emitem uma espécie de espectros ou imagens sutis, composta de átomos mais finos, que penetram nos órgãos dos sentidos. Desse modo, a mente recebe uma cópia ou réplica da coisa e é nisso que consiste o conhecimento. Demócrito faz referência aos objetos da experiência sensível ao mesmo tempo em que respeita o princípio racional de identidade.

Como se viu, a constituição do mundo segundo o atomismo abderiano só é concebida a partir da causalidade mecânica fruto do acaso. Ficam, portanto, algumas questões a serem respondidas e cujas respostas não encontramos no próprio sistema atomístico de Demócrito e nem no atomismo posterior: de onde provém o movimento inicial do átomo? Ele se encontra no próprio átomo ou há uma causa primordial que o justifica? Como se explica o processo de aglutinação e dispersão dos mesmos? Que elementos nos levam a sustentar que na estrutura externa dos átomos, por suas diferenciações, encerram os elementos da natureza? Como se vê, tais respostas não são encontradas no próprio atomismo, o que sugere mais uma construção intelectual de um sistema não sustentado pela observação. Mais uma vez, estamos diante de um processo de fabricação da realidade comum aos seres humanos desde as bases da construção do conhecimento ocidental. Tal prática perdurará e a própria concepção de átomos se apresentará sob várias facetas até a atual física quântica, a maioria delas produto de nosso imaginário criativo que, não encontrando respostas na Física, assenta-se na metafísica. E parece ser esse o elemento definidor da filosofia: fazer filosofia é tentar dizer algo de metafísico. Só que, como se verá, tal procedimento não é exclusivo da filosofia; a própria ciência, em muitas ocasiões, sobrepõe a teoria à realidade e espera que a segunda confirme a as verdades da primeira. Quando isso não acontece, temos mais um sistema metafísico, agora, não no interior da filosofia, mas da própria ciência.

Como se verá, a história do atomismo subsiste aos séculos e nossa concepção atual de mundo é fruto do desenvolvimento dessa história. $\mathrm{Na}$ esteira do atomismo de Demócrito encontramos o neoatomismo de Epicuro (341-270 a.C.) e de Lucrécio (96-55 a.C.).

Famoso por ter uma doutrina sempre confundida com o incentivo pela busca do gozo imoderado dos prazeres mundanos, como se não se distinguisse do hedonismo puro e simples ${ }^{7}$, Epicuro representa um marco na mudança da concepção atômica que o precedia. De sua obra conservou-se,

\footnotetext{
${ }^{7}$ Essa interpretação da vida e doutrina de Epicuro contém muito mais um caráter anedótico do que real, pois, segundo Diógenes Laércio (Vidas, p. 286-288), no "Jardim de Epicuro" vicejava uma autêntica comunidade, onde o mestre e discípulos viviam de maneira quase ascética, consumindo apenas hortaliças que eles próprios cultivavam, às quais acrescentavam apenas pão e água, ou ainda queijo em ocasiões especiais.
} 
também, três cartas que costumam ser apontadas como a súmula do pensamento epicurista: a primeira, dirigida A Heródoto, trata da física; a segunda, dirigida A Pítocles, trata da meteorologia e da astronomia; a terceira, dirigida $A$ Meneceu, trata das concepções sobre a vida humana. É mais especificamente na carta $A$ Heródoto que se encontra o cerne do atomismo físico epicurista. A Física, também tida como a ciência do nascimento e da morte, abrange toda teoria da natureza.

Para Epicuro, da mesma forma que para Demócrito, não existe nada além das coisas físicas ou corpóreas e de sua ausência (do átomo e do vazio). Mas, engana-se quem porventura espera que seja Demócrito sua principal inspiração; na verdade, sua admiração é muito maior por Anaxágoras e os seus átomos assemelham-se mais às homeomerias anaxagorianas do que com o sistema democritiano, ao qual ele se opõe. A principal modificação que Epicuro introduz no mecanicismo atômico de Demócrito é que, se para os abderianos os átomos seriam simplesmente ideias, para Epicuro os mesmos são corpos, que possuem peso e outras qualidades materiais - e não existiria outro critério para o conhecimento que não a sensação. No entanto, Epicuro não parece se atentar para alguns problemas advindos dessa forma de pensar: como é que um filósofo, que fixa tudo a partir dos sentidos, pode conceber "realidades" invisíveis como o átomo e o vazio? Outra coisa, como provar a existência do vazio que, por definição, não é sensível?

Outra modificação Epicuro introduz no pensamento de Demócrito. Se o segundo explicava o movimento sem apontar nenhuma justificativa teleológica para o mesmo (tudo acontece ao acaso), Epicuro explica o movimento pelo peso dos átomos, que é responsável pela sua queda ${ }^{8}$. Mas, por esse tipo de movimento, os átomos cairiam paralelamente e jamais se chocariam para produzir a diversidade das coisas. Daí é que Epicuro introduz a ideia de um novo tipo de movimento, a declinação ("clinâmen"). Por meio dela os átomos se desviariam de sua trajetória retilínea para colidir com outros e produzir a diversidade do real. No entanto, mais um questionamento pode ser levantado sobre esse tipo de mecanicismo: e o que explica essa declinação? Existiria um fator externo atuando sobre ela? Para Epicuro não. A declinação não se explica porque é manifestação da liberdade do átomo. Sendo assim, ele cria uma espécie de teoria materialista da liberdade, onde, no lugar da necessidade, introduz-se uma indeterminação natural.

Epicuro se opôs com grande aversão às concepções fundamentais dos platônicos e dos aristotélicos, tornando-se o primeiro materialista consciente do próprio materialismo, como clara e explícita negação do suprassensível, do incorpóreo e do

\footnotetext{
${ }^{8}$ Diferentemente de Demócrito que indicava como atributos dos átomos o tamanho e a forma, Epicuro acreditava que o peso, também, é inerente ao átomo.
} 
imaterial, e, consequentemente, da imortalidade e imaterialidade da alma (ROCHA, 2007, p. 35).

Por questões morais e não somente físicas, a introdução do "clinâmem" na teoria de Epicuro tinha um segundo propósito, a saber, abolir as imposições da necessidade, do destino e dos deuses e introduzir o homem na história como sendo o senhor de si, sem constrangimento e livre para ser feliz. A própria ataraxia (prazer em repouso) apregoada por Epicuro é expressão máxima dessa liberdade ou libertação (dos deuses, do destino, do medo da morte, etc.), e se resume em suas quatro máximas: "não há que temer aos deuses"; "morte significa ausência de sensações"; "é fácil procurar o bem"; e "é fácil suportar o mal". Com sua teoria, consegue suprir dois ideais que guiaram a história da humanidade: o de dar inteligibilidade à natureza formando um sistema de ideias coerente, lógico e necessário (da mesma forma que os seus antecessores o fizeram), e o de pensar em um ideal democrático da liberdade humana. Aqui a fabricação da realidade conjuga-se com a própria realidade.

Mas, retornando à questão do atomismo epicurista e do seu funcionamento que, excetuando o que foi supramencionado, parece-se muito ao de Demócrito (na questão do átomo e do vazio, do princípio de conservação, o caráter dos átomos, do infinito e do imutável e das propriedades do átomo), uma coisa chama a atenção e merece uma alínea: sua concepção de mundos possíveis. Retomando Diógenes Laércio ( $O p$. Cit., p. 293), temos a seguinte afirmação:

\begin{abstract}
Além disso, existe um número infinito de mundos, tanto semelhantes ao nosso como diferentes dele, pois os átomos, cujo número é infinito como acabamos de demonstrar, são levados em seu curso a uma distância cada vez maior. E os átomos dos quais poderia formar-se um mundo, ou dos quais poderia criar-se um mundo, não foram todos consumidos na formação de um mundo só, nem de um número limitado de mundos, nem de quantos mundos sejam semelhantes a este ou diferentes deste. Nada impede que se admita um número infinito de mundos.
\end{abstract}

O que se vê aqui, desde a Antiguidade, é a defesa da possibilidade da existência de uma infinidade de mundos possíveis. E isso só é possibilitado pela postulação do átomo enquanto componente constitutivo e básico de todas as coisas. O que em filosofia é chamado de um mundo possível é uma entidade hipotética que nos permite falar sobre, e estudar, os vários aspectos em que o universo poderia ter sido diferente. Paralelo a cada aspecto ou combinação de aspectos no mundo real, existe um outro aspecto que num mundo possível poderia ter sido diferente. "Mas os mundos também são em número infinito, uns semelhantes a este aqui, outros diferentes. Pois os átomos sendo em número infinito, como acabou de ser demonstrado, são 
levados às maiores distâncias" (EPICURO, Carta a Heródoto, § 45 apud DUMONT, Op. Cit., p. 520).

Segundo Jean Bayet (apud DUMONT, Op. Cit., p. 555), a filosofia de Epicuro foi "tão vulgarizada no mundo romano que o poeta Lucrécio experimentou uma necessidade urgente de oferecer ao público culto uma exposição sistemática da doutrina do Jardim, compondo, à maneira dos présocráticos, um poema intitulado Da Natureza". No entanto, apesar de tal poema representar uma ponte entre o atomismo antigo e o seu ressurgimento na Idade Moderna, o mesmo não apresentou nenhuma novidade frente o pensamento de Epicuro. As questões como a do peso e da declinação, do vínculo entre declinação e liberdade, das sensações, da alma e da morte, permanecem quase que intocadas. Mesmo assim, Da Natureza, primeiro texto filosófico em latim, é considerado como um dos maiores poemas filosóficos de todos os tempos, mas que se limita a expor em versos o pensamento de Epicuro, ressaltando sua crítica à religião como causa dos temores do homem. O que se pode chamar de inovação no referido texto em relação ao pensamento de Epicuro é que nele Lucrécio Caro (séc. I a.C.) reinventa o atomismo promovendo uma comparação entre os átomos e as letras do alfabeto: "da mesma forma como alguns átomos são lisos e outros curvos, também algumas letras são abertas e outras fechadas. Da mesma maneira que a combinação de algumas letras produz as palavras 'branco' ou 'perfume', a combinação de alguns átomos produz uma cor branca ou um perfume" (ROCHA, Op. Cit., p. 38). No entanto, sabe-se bem que, da mesma forma que uma combinação de algumas letras pode não formar palavra alguma, a combinação de alguns átomos pode não produzir objeto algum, ser apenas um amontoado disforme de átomos.

Certo é que as ideias de Lucrécio ultrapassaram da Antiguidade à Idade Média, e teriam sido "redescobertas", em 1417, por Poggio Braccioli. Enfatiza-se o termo redescobertas visto que o seu pensamento fora conhecido por outros autores em outras ocasiões. Pelo menos é o que afirma Alistair Crombie (2007, p. 38):

\footnotetext{
Certamente as ideias de Lucrécio não eram desconhecidas antes desta data: elas aparecem, por exemplo, nos escritos de Hrabanus Maurus, Willian de Conches e Nicolas de Autrecourt. Porém, o poema de Lucrécio parece ter sido conhecido apenas em partes, em citações nos livros dos gramáticos. Ele foi impresso mais tarde no final do século XV e depois disto muitas vezes.
}

Como foi dito, tal pensamento é muito mais importante pela divulgação e propagação de um atomismo que teria começado por Leucipo e Demócrito e desaguado no atomismo de Epicuro do que por suas contribuições originais. Como se verá, mesmo diante de todos os problemas concernentes à produção do conhecimento na Idade Média, o atomismo 
sobreviveu e teria sido ele a causa da condenação de Galileu que fora considerado herético por sua adesão a doutrinas atomistas.

Encerra-se, portanto, a reflexão acerca da construção da realidade na Antiguidade grega. O objetivo do presente foi o de buscar a origem e os fundamentos da concepção de mundo enquanto criação humana, os fundamentos de uma ontologia que insiste em fabricar a realidade. Concluímos que, o que parece subjazer à intenção dos gregos era conceber um sistema cuja objetividade fosse salvaguardada, que tivesse uma conotação de universalidade e de identidade formal. Em outras palavras, salvaguardar a objetividade através da homogeneidade da realidade com o pensamento, afastando o sujeito conhecedor da descrição do mundo.

Certo é que foram tais ideias que deixaram o legado para o que no século XX havia de ser entendido como átomo e sobre sua funcionalidade. $\mathrm{O}$ retorno às bases gregas nos dá uma noção de que, mesmo sem a percepção das aplicações práticas recentes, a funcionalidade do átomo sempre foi reconhecida como explicação racional do real. É importante o conhecimento de tal história e o reconhecimento de que, se houve alguma originalidade na inspiração criativa da ideia de átomo, essa originalidade foi, de fato, grega.

Por fim, o que gostaríamos de salientar nesse texto, refere-se à escolha do átomo como viés de exposição da metafísica grega. Sabe que até o desenvolvimento da física contemporânea, o que era conhecido como átomo (primeira partícula indivisível, na etimologia grega), não era mais que um subterfúgio para explicar (ou justificar) fenômenos até então inexplicáveis que estavam diluídos na tradição mitológica. $\mathrm{O}$ átomo enquanto realidade física só pode ser considerado como tal, a partir dos trabalhos em química, por Boyle (1627-1691); em eletromagnetismo, por Faraday (1791-1867); e, principalmente, em física atômica, por Ernest Rutherford (1871-1937) e Niels Bohr (1885-1962), aos quais se deve sua descrição moderna. Antes disso, ele nada mais era do que uma conjectura, utilizada principalmente associada aos princípios mecânicos da matéria. 


\section{Referências bibliográficas}

ARISTÓTELES. Metafísica. Trad. Leonel Vallandro. Porto Alegre: Editora Globo, 1969.

CROMBIE, Alistair. Medieval and Early Modern Science. In:

MCDONNELL, John J. The Concept of an Atom From Democritus to John Dalton. The Edwin Mellen Press, 1992.

DUMONT, Jean-Paul. Elementos de história da filosofia antiga. Trad. Georgete M. Rodrigues. Brasília: Editora Universidade de Brasília, 2004. GALENO. Sobre a Medicina Empírica, 1259, B apud Os Pré-Socráticos. Trad. Anna L. A. A. Prado. São Paulo: Nova Cultural, 2000. (Coleção Os Pensadores).

HEISENBERG, Werner. Física e Filosofia. Trad. Jorge Leal Ferreira. 3. ed. Brasília: Editora Universidade de Brasília, 1995.

LAÊRTIOS, Diôgenes. Vidas e Doutrinas dos Filósofos Ilustres. Trad. Mário da Gama Kury. 2. ed. Brasília: Editora Universidade de Brasília, 2008.

PARMÊNIDES. Da Natureza. Trad. José Trindade Santos. São Paulo: Loyola, 2002.

ROCHA, Gustavo Rodrigues. História do atomismo: como chegamos a conceber o mundo como o concebemos. Belo Horizonte: Argvmentvm, 2007.

SANTOS, José Trindade. Interpretação do Poema de Parmênides. In: PARMÊNIDES. Da Natureza. Trad. José Trindade Santos. São Paulo: Loyola, 2002.

Autor(a) para correspondência: Eduardo Simões, Universidade Federal do Tocantins, Quadra 109 Norte, Avenida NS15, ALCNO-14, Plano Diretor Norte, CEP77001-090, Palmas - TO, Brasil. eduardosimoes@mail.uft.edu.br 